\title{
The Tradition of Mappano' Lolo as Ritual Communication of the Bugis Bone Community
}

\author{
Nur Aisyah Rusnali* \\ Islamic Communication and Broadcasting \\ IAIN Bone \\ Watampone,Indonesia \\ rusnaliaisyah@gmail.com
}

\author{
Syahrianti Syam \\ Islamic Communication and Broadcasting \\ IAIN Bone \\ Watampone, Indonesia \\ antysos@yahoo.com
}

\begin{abstract}
The Mappano' Lolo ritual is a tradition conducted by the Bugis Bone community as a cultural heritage of their ancestors. This ritual, which is conducted as a part of the akikah process, is performed for a newborn child. This tradition is full of symbols, meanings, and cultural values that are unique for the Bugis ethnic. This research was conducted to examine more deeply the process of implementing the Mappano' Lolo tradition, its meanings, and its values. This is a qualitative research with a communication semiotic approach. Semiotics has been widely used for research on cultural traditions because this approach is considered capable of explaining in detail the meaning of cultural values which are full of symbols. Community life will never be separated from hereditary traditions since ancient times. This is because tradition is considered capable of providing positive values in human life who are competing every day with modernization. A good tradition that is in line with religious and cultural values must be preserved and saved so that it is not eroded by era.
\end{abstract}

\section{Keywords - tradition, mappano' lolo, ritual communication}

\section{INTRODUCTION}

The Bugis community is known to be rich in traditional traditions that have been carried out from generation to generation. Tradition is a part of culture which is resulted from human creation, taste, and initiative. Culture cannot be separated from society, because it regulates many things and is related to the values that guide life. The current development, of course, has an impact on ancestral traditions which are full of traditional rituals. Some have been preserved, but not a few have been lost. This is certainly a homework for the younger generation as a mouthpiece for the next generation. Ritual communication is a communication function used to fulfill human identity as an individual, as a member of the social community, and as an element of the universe [1]. Communication rituals are closely related to the emotional bond between the individual and the society.

Customary rituals are a way for ancestors to communicate with the community. There are many symbols that contain messages and teachings of kindness to be conveyed in a traditional ritual. Rohtenbuhler describes some of the characteristics of ritual such as: ritual is action, ritual is performance, ritual is awareness and willingness, irrationality, ritual is not just recreation, collective, ritual is an expression of social relations, subjunctive and not indicative, effectiveness of symbols, condensed symbols, expressive or aesthetic behavior, customary behavior, regular repetitive behavior, uninformed communication, and sacred [2]. Mulyana said that ritual communication is carried out by a community which often performs different ceremonies throughout the year and throughout life. Anthropologists call it the rites of passage, starting from birth ceremonies, circumcisions, birthdays (singing Happy Birthday songs and cutting cakes), engagement, marriage, to death ceremonies[3].

The Bugis Bone community in general is still very maintain the traditional rituals in daily life. Every newborn child in the land of Bugis Bone will go through the Mappano' Lolo ritual which is part of the akikah process. The Mappano' Lolo tradition comes from the Old Buginese language. The word Mappano 'means to lower, while Lolo means placenta. So the meaning of the term Mappano' Lolo is to derive the placenta. This tradition has existed since ancient times, where every placenta of a newborn child is placed on the top of the ceiling of the house. Most of the ancient Bugis houses were houses on stilts. On the roof there is a support board called Rakkiyang. It is in this part of the Rakki that the placenta is placed. However, along with the times, the Bugis stilt houses have changed into houses made of concrete. Thus, the placenta is no longer placed in Rakkiyang, but it is hang on the house poles. At the time of akikah, the placenta will be unloaded from its storage area. This process is usually carried out by a Sanro Kampong or village shaman who begins with a few rituals.

In its implementation, Mappano' Lolo tradition have many symbols, meanings and values of life. This tradition established orderly systems in a fixed order. Traditions are carried out in accordance with the behavior taught by previous ancestors. Like traditional rituals in general, the Mappano' Lolo tradition has the aim of respecting, worshiping, being grateful, and asking for the safety of the ancestors. However, ritual communication is often seen as clashing with religious teachings. In fact, culture and religion go hand in hand as part of society. Therefore, this research was conducted to examine more deeply the process of implementing the Mappano' Lolo tradition, as well as the meanings and values contained in the symbols of the ritual communication. 


\section{METHODS}

This is a qualitative research which aims to explain phenomena in depth through in-depth data collection [4]. Sources of data in this study are community leaders, traditional elders, and several communities who carry out the Mappano' Lolo ritual tradition. Data obtained from in-depth interviews, observations, and literature study. The data obtained were then analyzed by means of explorative, descriptive, explanative, and evaluative way.

\section{RESULTS AND DISCUSSION}

The Mappano' Lolo ritual performed by the Bugis Bone community is a hereditary tradition as a legacy from their ancestors. It is not without reason that this tradition is still being carried out today. According to the belief of the Bugis Bone community, there are many meanings of goodness in every symbol of the implementation of the Mappano' Lolo custom. This ritual is carried out during the akikah procession of a child. In Islam, the law of implementing akikah is Sunnah Muakkad (greatly recommended). As stated in the hadith of the Prophet Muhammad peace be upon him, "Every child is required by their akikah".

\section{Implementation of the Mappano' Lolo tradition}

The ritual sequences in the implementation of the mappano' lolo tradition, namely:

\section{Massawa' \\ 2. Mattimpu \\ 3. Barasanji \\ 4. Massompung Gemme \\ 5. Marrebbang Lolo}

The Mappano' Lolo ritual communication is carried out prayerfully and with full sincerity. This ritual is initiated by making "sawa". Sawa' is a food made of glutinous rice and coconut milk, wrapped in coconut leaves, tied, then steamed. This Sawa', will later be used in the "mattimpu" procession which means to feed food. This procession is carried out by a "sanro" or village shaman. If the child is still in a baby state, "sawa" is only in a small portion given into the baby's mouth. In this ritual, a food called "Sokko" is prepared first. This food is made from two kinds of sticky rice, namely black and white sticky rice. Then the white sticky rice is added with turmeric, to make it look yellowish.

The meaning of these colorful sokko is that the black sokko symbolizes the earth, the white one symbolizes water. This case means that soil and water are very important elements of life, so it is hoped that all the elements of life of the baby can be fulfilled.

After the mattimpu procession, there is a barasanji ritual. This ritual is usually performed at every important ceremony in the Bugis Makassar tradition, such as marriage, housewarming, akikah, etc. Despite reaping pros and cons, this tradition is still widely practiced by the Bugis community, especially in Bone regency. Barasanji ritual is performed by several people and led by a priest. People who are involved in the barasanji process are usually termed "pabbarasanji". They will recite verses from the Koran in turn while sitting. After that, in standing position, they reading the prayers of the Prophet and in this time, the next ritual is carried out, namely "massompung Gemme", or cutting a portion of the hair of newborn child. This haircut is done as exemplified by the Prophet and this hair cutting process is carried out in turn by elder people and newborn child's relatives.

The last ritual is Marrebbang Lolo. The baby's arid that has been placed on the roof of the house is then put down and put into "wala suji". Wala suji is a rectangular box made of woven bamboo. In the belief of the Bugis-Makassar community, wala suji is a symbol of the four directions of the wind. In this view, both girls and boys of the BugisMakassar tribe must have values containing in the 4 sides of wala suji. These values are acca (intellectuality), warani (courage), lempu (honesty), and asugireng (stability). The marrebbang lolo ritual is the culmination of the mappano' lolo procession and it is the last ritual.

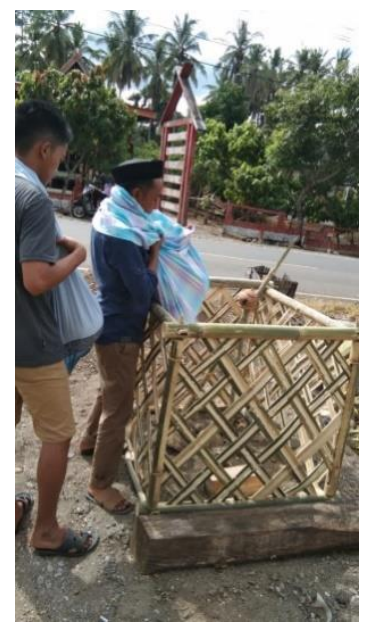

Fig. 1. Ritual Marrebbang Lolo

\section{Mappano' Lolo Tradition as Ritual Communication for the Bugis Bone Community}

Indonesia is a country that is rich in traditions inherited from our ancestors. Almost every tribe in Indonesia has a unique tradition or customary ritual that is full of meanings so it is interesting to be studied. Thus, it is not surprising that anthropologists, socialists and cultural researchers from various parts of the world come to study these unique traditions. Traditions are created by humans in the form of customs, namely habits emphasized on supernatural habits which include cultural values, norms, laws and related rules (Darwis, 2018). Indonesia is a country with a majority Muslim population and this case becomes a dilemma when many traditional rituals are considered incompatible with Islamic law. On the one hand, the customary tradition is a universal wealth and inheritance as a characteristic of the nation, but on the other hand, many traditions are abandoned because they are considered not in line with religious norms.

Research on ritual communication has been carried out by many researchers in the field of communication. Among them is a research conducted by Marhani. The research describes how the Mappano cultural procession in the implementation of akikah in Batu Lappa community, ParePare city. There is also a research on ritual communication on the Atoni Pah Meto conducted by Manafe in Timor - East Nusa Tenggara. These researches illustrate how ritual 
communication cannot be separated from every aspect of community life.

Tradition can be defined as a culture that lasts from generation to generation which contains noble values, norms, customs, and rules. Tradition is not something that can be changed, it is combined with various human actions and considered as a whole. Traditional ceremonies as a form of tradition can be used as a means of cultural preservation. In this case, tradition is a manifestation of the life of each person and group of people [5]. Differences in traditions in each region are caused by geographic location. On the island of Sulawesi, where most of the land is agricultural rice fields, the traditional ceremony that is often held is the harvest festival, known as Mappadendang. Meanwhile, on the island of Java, which contains a series of mountains, the Kasada tradition has become an annual agenda for the Javanese people.

Until now, customary traditions are still widely implemented because of good communication between parents as previous generation and future generation. Ritual communication is part of every tradition that is carried out. Ritual communication is an attempt to involve cultural knowledge in the practice of local variants of speechcentered human interaction. Ritual communication is rich in art and it does not only involve speech, but it has a formula and is repeated in the context of certain social interactions [6]. The communication patterns that are built in ritual communication are the same and repetitive patterns. This is because ritual communication is considered a sacred ceremony which is a hereditary tradition so that the order cannot be reversed. Every process in ritual communication has meaning and is mutually sustainable. Could added that the communication pattern in a ritual perspective is not the sender sending a message to the recipient, but as a sacred ceremony where everyone takes part together in fellowship and gathers. [7]

As a tradition that becomes a habit and lives in a group or community, it does not necessarily become an accepted tradition but it goes through various processes to become a dynamic tradition and is carried out continuously. Tradition certainly describes the character of society and becomes the embodiment of various expressions of feelings towards a reality that occurs in society. Traditions are able to survive continuously because of the existence of good communication patterns from one generation to the next, so that existing traditions can be maintained and preserved into a habit that is carried out at a certain moment.

In the Mappano' Lolo tradition which is carried out by the Bugis Bone community, the rituals performed are well arranged in an irreversible order. Starting from the Massawa' procession to the last procession, namely Marrebbang Lolo. Each procession has its own meaning, so that the implementation process is traced as it was done by the previous generation or ancestors. According to the Bugis ethnic community, this procession does not contradict religious values at all. Although many rituals and symbols in the form of food are used in this procession, they are not offerings. Because all the prayers hoping for goodness are said only to the Lord of the worlds, Allah, the almighty.

A tradition that is conducted in community groups certainly does not have elements of crime, insult, or even deviating from religion. It can be ascertained that the traditions or rituals conducted are not against or contrary to religious teachings but rather a behavior that is conducted as a ritual that describes an expression of happiness, respect, gratitude, or as a form of communication to ancestors.

Not only as the expression of various feelings, but a tradition can also be a manifestation of the values of a culture inherent in society. This value is related to the feeling of what is expected or not and what is considered acceptable and not, which is then accepted by the community. Cultural values consist of conceptions that live in people's minds so that they become references and guidelines in determining attitudes and responding to problems or situations that occur. The values that exist in society are not only an identity or description of the community but also become a benchmark in determining a decision.

Likewise, with the Mappano' Lolo tradition, which is conducted in a predetermined order, is a tradition that certainly has value and becomes an expression of gratitude and an application of salvation so that a happy life and kindness will always accompany children who have just been born in the world. The hopes of parents, families, and society for babies who have just been born in the world are expressed in a ritual or tradition that has been passed down from generation to generation. Each step or sequence in the process of implementing this tradition certainly has a sacred meaning and to maintain the values that exist in this tradition, it is necessary to have good communication, respect and maintain the tradition so that this tradition can still exist in society.

\section{IV.CONCLUSION}

From the explanation above, it can be concluded that the implementation of the Mappano' Lolo ritual is conducted with full awareness and sincerity by the Bugis community in Bone Regency. The series of activities carried out are not just mere rituals, but these rituals are full of the meaning of goodness. The symbols used both from the food serving and the tools used have good meanings and expectations for the child. Ritual traditions are carried out by the community not only as performances and viewing materials, but they all have meaning, value, and meaning from generation to generation. In addition, the traditional traditions that are carried out will also strengthen the brotherhood between group members in one community, because it is impossible for the tradition to be carried out alone without assistance from the family and the surrounding environment. The implementation of this tradition is also expected to be able to maintain and preserve cultural values as inheritance from the ancestors so that they are not eroded by time. In Indonesia, of course there are many other traditions that are full of ritual communication in their implementation. This of course still opens the greatest opportunity for researchers in the fields of communication, sociology, and anthropology to study more deeply about ritual communication in order to enrich literature review on this topic.

\section{ACKNOWLEDGMENT}

We wish to express our deep thanks to our family, and all the members of Department of Ushuluddin and Dakwah 
for their kindness. Thanks for supporting us so this research can be complete

\section{REFERENCES}

[1] Y. D. Manafe, "Komunikasi Ritual pada Budaya Bertani Atoni Pah Meto di Timor-Nusa Tenggara Timur," J. ASPIKOM, Vol. 1, No. 3, p. 287, 2011.

[2] E. W. Rothenbuhler, Ritual Communication: From Everyday Conversation to Mediated Ceremony, Texas: Thousand Oaks. SAGE Publications, 1998.

[3] D. Mulyana, Ilmu Komunikasi Suatu Pengantar. Bandung: Rosda Karya, 2005.

[4] L. J. Moleong, Metode Penelitian Kualitatif, Revisi. Bandung: PT. Remaja Rosdakarya, 2013.

[5] S. Cathrin, "Tinjauan Filsafat Kebudayaan Terhadap Upacara Adat Bersih-Desa di Desa Tawun, Kecamatan Kasreman, Kabupaten Ngawi, Jawa Timur,” J. filsafat, Vol. 27,No.1, 2017.

[6] G. S. and E. Basso, "Ritual Communication," Bost. Med. Surg. J., Vol. 46, No. 14, pp. 281-282, 2009.

[7] N. Couldry, "Media Rituals Beyond Functionalism, dalam Media Anthropology," Thousand Oaks, SAGE Publ., 2005. 